\title{
Teologia do rito: A ação ritual como lugar da epifania do Mistério de Cristo
}

\author{
Orientador: Luiz Fernando Ribeiro Santana \\ Mestrando: Guilherme da Costa Vilela Gouvea \\ Área de Concentração: Teologia Sistemático-Pastoral \\ Linha de Pesquisa: Fé e Cultura \\ Projeto de Pesquisa: Questões atuais de Teologia Litúrgica
}

$\mathrm{O}$ rito tem seu lugar preponderante na liturgia da Igreja. Ele pertence ao mundo das mediações ativas da atitude religiosa, que abarcam desde o gesto mais simples à mais complicada celebração. Os ritos são, portanto, todas as ações orientadas à expressão religiosa, e na sua gênese está o sagrado, o divino, aquilo que é apontado como mistério. A irrupção de Deus na história, através da encarnação e ação redentora de seu Filho, o Cristo Jesus, possibilitará ao rito litúrgico cristão um elemento diferenciador de toda outra forma ritual, aquele de fazer sempre referência a uma "realidade" plena, isto é em nível de evento que já se efetuou, e ele é apropriadamente "a imagem" daquele evento, na própria "semelhança", que o liga a ele, traz o "sinal" da "realidade" a que se refere. A partir da teologia litúrgica da Constituição sobre a Sagrada Liturgia do Concílio Vaticano II, a Sacrosanctum Concilium, procuramos compreender como o rito litúrgico, na sua precípua função de anunciar e realizar, torna-se o lugar da epifania do Mistério Pascal de Cristo. Nele, o mistério de Cristo se manifesta de forma clara e luminosa, proporcionando à Igreja uma profunda experiência.

Palavras-chave: Rito. Liturgia. Mistério Pascal. 